\title{
Differences in U.S. Versus European Voluntary Earnings Forecasts
}

\author{
Ronald Stunda \\ Valdosta State University
}

This study provides empirical evidence regarding the credibility of management forecasts of earnings for both U.S. firms and a sample of firms from nine European countries. This study draws a distinction between U.S. firm forecasts and European firm forecasts. Earnings forecasts for U.S. and European firms were evaluated for the years 2000-2018. The evaluation consisted of conducting a study of bias and information content of the earnings forecasts for both firm groups. Bias results indicate that U.S. managers exert greater downwards earnings management on the forecast (relative to actual earnings), while the European managers exert greater upwards earnings management on the forecast (relative to actual earnings). Information content results indicate that for U.S. firms forecasts tend to exhibit a positive information-enhancing signal to users. For European firms, users interpret the forecast as being more noisy and potentially less informative.

\section{INTRODUCTION}

Discussions between the Financial Accounting Standards Board (FASB) and the International Accounting Standards Board (IASB) continue. Although FASB and IASB continue to move away from full convergence (Fitch Ratings Report, July 2014), there are areas where convergence continues on track. New revenue recognition standards were incorporated into GAAP after January 1, 2017, the new rules, which follow International Financial Reporting Standards (IFRS) affect the timing of revenue recognition, and the potential to make earnings less consistent over time. Some speculate that this new approach to revenue recognition may even affect the composition and release of voluntary earnings reports (Fogarty and Rogers, 2014).

Even though a mandatory change to IFRS for U.S. public companies is not expected for the foreseeable future, the discussion about the use of IFRS in the US continues. At the AICPA National Conference on Current SEC and PCAOB Developments in December 2016, the Chief Accountant of the SEC's Office of the Chief Accountant, Wes Bricker, indicated that although he does not foresee the use of IFRS for domestic registrants in the foreseeable future, he encouraged the FASB and IASB to work together to eliminate differences when in the best interest of capital markets. Similarly, in a public statement issued in January 2017, the outgoing SEC Chair expressed support for the development of highquality, globally accepted accounting standards, and suggested that the SEC support further efforts by the FASB and IASB to converge their accounting standards to enhance the quality and comparability of financial reporting (Corporate Finance Insider, January 2017).

Because of the global economy in which American companies operate, and American investors invest, managers and investors alike are facing uncertainty and risk. A way of minimizing this risk is 
through voluntary forecast information. Since U.S. public companies are required to release earnings performance data within 45 days after their year-end, this data is old and often times not as meaningful as forward-looking information. It then behooves investors to search out forecast information to enhance the decision-making process. One way for the investor and manager to compare current U.S. GAAP-based companies with European IFRS-based companies is to assess information content associated with their respective voluntary earnings releases. In doing so, we will see if similarities exist that make accounting convergence more palatable for U.S. firms and investors, or if significant differences have the potential to alarm the same parties. The purpose of this paper is to assess differences between U.S. and European voluntary earnings forecasts.

\section{LITERATURE REVIEW}

There are many similarities in the economic conditions in which European and U.S. firms operate. All countries included in this study have developed economies and a high degree of economic interdependence. So there is broad homogeneity between economic and social conditions in which the firms conduct business.

The justification for this type of research is, first and foremost, the importance of earnings forecasts to securities market practices. Forecasts are essentially produced for market participants. UK, German and Dutch studies have found that forecasts of earnings per share (EPS) are an important factor in share appraisal methods (Arnold and Moizer, 1984; Vergossen, 1993; and Pike, 1993). In many cases EPS forecasts are a crucial component of stock selection models. Further evidence of the value of EPS forecasts is the amount of time and effort dedicated to producing such forecasts by commercially oriented analysts and brokers (Capstaff, 1995).

In their analysis of U.S. consensus forecasts from 1974-1991, Dreman and Berry (1995) argued that average forecast errors are too large for investors to rely on their predictions, and only a small percentage of forecasts fall within a range considered acceptable to investors. Brown (1996) countered this interpretation by citing the overwhelming evidence that forecasts almost always provide the best available estimates when they are quarterly point forecasts. Therefore, forecasts might be used to devise profitable trading strategies by investors.

Accounting practices also affect the forecast information available. Rees (1998) reports a comparison of seven accounting measurement issues across fourteen European countries. In only two pairs, Sweeden and Norway, and Ireland and the UK, do countries use the same practices across the full set. It is apparent that even after the completion of the European Union (EU) harmonization effort, substantive differences in disclosure and measurement practices still exist within EU countries (a major reason why FASB is reluctant to commit to full convergence). Alford (1993) finds that only Ireland, the Netherlands and the UK have accounting systems which are relatively free from the influence of taxation. In other European countries, managers have an incentive to manage earnings downward to minimize taxes. Stotz (2016) included emerging nations along with developed nations and finds that forecasts are optimistically wrong by $25 \%$.

The quality of disclosure in accounting statements can be expected to affect forecast accuracy. This has been demonstrated with regard to segment reporting (Baldwin, 1984; Hopwood, 1982), while Lang and Lundholm (1996) provide evidence that forecasts are more accurate for firms with more informative disclosure policies. Saudagaran and Biddle (2002) provide a ranking of effectiveness and rank the top nine European countries with the highest quality of disclosure. Basau (2006) confirms that forecasts emminating from these countries possess fewer forecast errors than other European countries with less informative financial disclosure. These nine countries will be used as the basis for assessing European earnings forecasts and they are listed in Table 1 below. 
TABLE 1

\section{LIST OF EUROPEAN COUNTRIES CONTAINED IN THE STUDY}

\begin{tabular}{|rl|}
\hline \multicolumn{1}{|l|}{ Country } \\
\hline 1. & Belgium \\
\hline 2. & France \\
\hline 3. & Germany \\
\hline 4. & Ireland \\
\hline 5. & Italy \\
\hline 6. & Netherlands \\
\hline 7. & Spain \\
\hline 8. & Switzerland \\
\hline 9. & United Kingdom \\
\hline
\end{tabular}

Table 1 lists the European countries with the highest degree of disclosure information as determined by Saudagaran and Biddle (2002)

An analysis of the Institutional Brokers Estimate System (IBES) and the Dow Jones News Retrieval Service (DJNRS) was made for U.S firms, and IBES and Worldscope Data for European firms, for the years 2000-2018 in an attempt to determine the number of quarterly forecasts recorded during this time frame. Results are shown in Table 2.

TABLE 2

QUARTERLY FIRM POINT FORECASTS BY SAMPLE GROUP

\begin{tabular}{|lcc|}
\hline Year & U.S. Firms & European Firms \\
\hline 2000 & 504 & 318 \\
\hline 2001 & 489 & 314 \\
\hline 2002 & 517 & 389 \\
\hline 2003 & 476 & 362 \\
\hline 2004 & 530 & 371 \\
\hline 2005 & 521 & 328 \\
\hline 2006 & 482 & 340 \\
\hline 2007 & 509 & 337 \\
\hline 2008 & 473 & 352 \\
\hline 2009 & 495 & 361 \\
\hline 2010 & 515 & 313 \\
\hline 2011 & 487 & 356 \\
\hline 2012 & 501 & 329 \\
\hline 2013 & 488 & 347 \\
\hline 2014 & 510 & 333 \\
\hline 2015 & 519 & 341 \\
\hline 2016 & 531 & 329 \\
\hline 2017 & 505 & 338 \\
\hline 2018 & 520 & 318 \\
\hline
\end{tabular}

Table 2 indicates the numbers of quarterly earnings forecasts made by U.S. firms from 2000 through 2018, as reported by IBES and the Dow Jones News Retrieval Service and for European firms for the same period as reported by IBES and Worldscope Data.

Prior research in the study of U.S. voluntary earnings forecasts finds that managers release information that is unbiased relative to subsequently revealed earnings and that tends to contain more bad 
news than good news (Baginski et al, 1994; Frankel, 1995). Such releases are also found to contain information content (Patell, 1976; Waymire, 1984; Pownell and Waymire, 1989). Although forecast release is costly, credible disclosure will occur if sufficient incentives exist. These incentives include bringing investor/manager expectations in line (Ajinkya and Gift, 1984), removing the need for expensive sources of additional information (Diamond, 1985), reducing the cost of capital to the firm (Diamond and Verrechia, 1987), and reducing potential lawsuits (Lees, 1981).

All of the aforementioned empirical studies have common characteristics, they assess voluntary earnings forecasts of only U.S. firms. The research question addressed in this study is: Do voluntary earnings forecasts differ depending upon whether or not they were issued in the U.S. versus the selected European countries? For several years researchers have found that some degree of earnings management may exist in mandatory earnings disclosures. I argue that incentives leading to earnings management may manifest in voluntary disclosures as well. If the potential exists for voluntary disclosures to be managed, then to what extent do investors rely upon the forecast information, and does this information content differ by entity (i.e., U.S. versus Europe)?

In addressing these research questions, I rely upon literature that indicates potential earnings management during periods with differing incentive structures. DeAngelo (1986) shows that managers have incentives during management buyouts to manage earnings downward in attempt to reduce buyout compensation. Collins and DeAngelo (1990) indicate that earnings management occurs during proxy contests, and market reaction to earnings during these contests is different than during non-contest periods. DeAngelo (1990) finds that managers have incentives during merger activities to manage earnings upward so as to convey to current stockholders that the potential merger will not adversely affect their investment. Perry and Williams (1994) find that management of accounting earnings occurs in the year preceding "going private" buyouts. Stunda (1996) finds that managers exert greater upward earnings management during mergers and acquisitions. And Stunda (2003) finds greater earnings management when a firm is under Chapter 11 protection.

This study assesses any differences that may be present in information content on the voluntary forecast of earnings by U.S. firms versus selected European firms during these periods. In accomplishing this, the presence of earnings forecast management is tested by using bias measures along with the market reaction to the forecasts. Based upon statistical analysis, conclusions are reached that identify whether or not environment is a factor that has the potential for influencing voluntary earnings forecasts. The results have implications for all public firms in both the U.S. and Europe.

\section{HYPOTHESES DEVELOPMENT}

\section{Hypotheses About Bias of Management Forecast}

As previously noted, most past studies of voluntary earnings forecasts do not find evidence of bias in such disclosures. These studies of management forecasts must be considered along with the earnings management literature. For instance, voluntary disclosures facilitate additional information to the investor at a lower acquisition cost. However, if only partial communication flows from management to investors and acquiring full information is costly, there exists asymmetric information and the potential for earnings management of the forecast.

If the same degree of earnings management (whether positive or negative) exists in both the forecast of earnings and actual earnings, the expectation is that there would be no difference in forecast error. If, however, the ability to perform earnings management is anticipated but not realized, some difference of forecast error would be present. If greater upward earnings management of the forecast occurs (or less actual earnings management), a negative forecast error should exist. If greater downward earnings management of the forecast occurs (or less actual earnings management), a positive forecast error should result. Thus, the first hypothesis tests for the existence of forecast error. The null hypothesis tested is:

H1: Average management forecast error ( actual EPS - management forecast of EPS) for U.S. firms equals zero. 
Applying this same logic to the firms representing the nine selected European countries, results in the second hypothesis which also tests for the existence of forecast error. The null hypothesis tested is:

H2: Average management forecast error (actual EPS - management forecast of EPS) for European firms equals zero.

\section{Hypothesis About Information Content of Accounting Earnings and Management Forecasts}

If mandatory disclosures of earnings contain some degree of earnings management, then voluntary disclosures may possess the potential for such earnings management as well. Investors may react to managed earnings in one of two ways; they may discount the information as additional noise, or they may view this information as enhancing the properties of the signal (i.e., in terms of amount or variance). Research during the past two decades has shown that accounting earnings possesses information content. Current literature finds that the information content of earnings announcements is different during nonroutine periods (i.e. stock proxy contests, mergers and acquisitions, buyouts, Chapter 11 proceedings, etc.).

If investors interpret managed earnings forecasts as just additional noise, the market would discount this information. If, however, investors view the managed earnings forecast as a positive (or negative) signal form management, the market would not discount the information. The expectation for information content of management forecasts in varying economic environments would revolve around these two notions. These alternative notions suggest the following null hypothesis:

H3: The information content of management forecasts does not differ between U.S. and European firms.

\section{DATA AND METHODOLOGY}

The sample consists of quarterly management forecast point estimates made during 2000-2018 The sample met the following criteria: 1) The management earnings forecast was recorded by the Dow Jones News Retrieval Service (DJNRS) for U.S. firms and Worldscope for European firms. 2) Security price data was available from the Center for Research on Security Prices (CRSP) for U.S. firms and the AMADEUS database for European firms. 3) Earnings data was available from Compustat, and Compustat Global for U.S. and European firms respectively. 4) Analyst forecast information was available on the Institutional Brokers Estimate System (IBES). 5) The samples consist of firms which made at least one management earnings forecast in each sample period. Table 3 provides details on the samples

TABLE 3

\section{STUDY SAMPLES BY SAMPLE PERIOD}

\begin{tabular}{|lcc|}
\hline $\begin{array}{l}\text { Years } \\
\text { forecasts }\end{array}$ & Number of U.S. forecasts & Number of European \\
\hline & & 5,667 \\
\hline $2000-2018$ & 5,991 & 5 \\
\hline
\end{tabular}

Table 3 Forecasts reflect the firms selected in the sample after removing those eliminated for insufficient data as enumerated above. The information was obtained from the Dow Jones News Retrieval Service for U.S. firms and Worldscope for European firms. 


\section{TEST OF HYPOTHESES 1 AND 2}

The management forecasts of earnings must be related to actual earnings in order to determine if bias exists. McNichols (1989) analyzes bias through the determination of forecast error. Stated in statistical form, the hypothesis is represented in Equation 1 as follows:

$$
\sum \underset{n}{f e_{i}}=0
$$

This equation describes how forecast error is determined:

where: $\mathrm{fe}_{\mathrm{i}}=$ forecast error of firm $\mathrm{i}$ (forecast error $=$ actual eps - management forecast of eps), Deflated by the firm's stock price 180 days prior to the forecast.

In order to test hypotheses 1 and 2, firm forecasts included in the study samples were analyzed. Statistical analysis is performed on the samples in order to determine if the average forecast error is zero. McNichols (1989) and DeAngelo (1988) conduct a t-test on their respective samples in addition to a Wilcoxon signed rank test. Lehmann (1975) reports that the Wilcoxan tests has an efficiency of about 95\% relative to a t-test for data that are normally distributed, and that the Wilcoxan test can be more efficient than the t-test for non-normal distributions. Therefore, this analysis consists of performing a ttest and a Wilcoxan signed rank test on the average cross-sectional differences between actual earnings per share and the management forecast of earnings per share.

\section{HYPOTHESES $1 \& 2$ RESULTS}

Tests of hypotheses 1 and 2 were conducted on a total of 5,991 forecasts for U.S. firms, and 5,667 forecasts for European firms. Table 4 contains the results of this test.

\section{TABLE 4}

\section{AVERAGE MANAGEMENT FORECAST ERROR DEFLATED BY FIRM'S STOCK PRICE 180 DAYS PRIOR TO FORECAST}

\begin{tabular}{|c|c|c|c|c|c|}
\hline \multicolumn{6}{|c|}{ Model: $\quad \sum \underset{\mathrm{fe}}{\mathrm{fe}_{\mathrm{i}}}=0$} \\
\hline $\begin{array}{l}\text { n U.S. forecasts } \\
\text { Deviation } \quad \text { (t-statistic) }\end{array}$ & Mean & Medium & Minimum & Maximum & Standard \\
\hline $\begin{array}{l}5,991 \\
(2.36) *\end{array}$ & 0.15 & $0.08 * *$ & -0.127 & 0.229 & 0.0015 \\
\hline $\begin{array}{l}\text { n European forecasts } \\
\text { (t-statistic) }\end{array}$ & Mean & Medium & Minimum & Maximum & Deviation \\
\hline $\begin{array}{l}5,667 \\
(2.42)^{*}\end{array}$ & -0.14 & $-0.10 * *$ & -0.021 & -0.222 & 0.0019 \\
\hline \multicolumn{6}{|c|}{ * Significant at the .01 level (two-sided test). } \\
\hline \multicolumn{6}{|c|}{ ** Significant at the .01 level using the non-parametric sign-rank test. } \\
\hline \multicolumn{6}{|c|}{$\mathrm{fe}_{\mathrm{i}}=$ forecast error of firm i (actual eps - management forecast of eps) } \\
\hline
\end{tabular}

Table 4 assesses the bias of voluntary earnings forecasts for all quarterly forecasts included in both samples. This analysis is made to determine a baseline measurement of all forecasts in this study to ensure that results are comparable with prior studies that assess forecast bias. 
Table 4 indicates that the mean forecast error for U.S. forecasts is 0.15 with a p-value of .01, indicating a downward bias in the management forecast among U.S. firms. European firms have a mean forecast error of -.14 with a p-value of .01, indicating an upward bias in the management forecast among European firms. Using the distribution-free rank test, significance is observed at the .01 level for both groups. These results are consistent with the preponderance of extant earnings forecast literature that indicates that management forecasts tend to reflect more bad news in the forecast relative to actual earnings for U.S. firms, and confirms Stotz, 2017 findings that European forecasts tend to have an upwards bias associated with them. As a result, Hypotheses 1 and 2, which state that average management forecast error equals zero, is overturned for both U.S. and European firms.

\section{TEST OF HYPOTHESIS 3}

The purpose of this test is to assess the relative information content of management earnings forecasts between U.S. and European firms. The following model in Equation 2 is used to evaluate information content:

$$
C A R i t=a+b_{1} U E i t+b_{2} U E E i t+b_{3} M B i t+b_{4} B i t+b_{5} M V i t+e i t
$$

where: CARit $=$ Cumulative abnormal return forecast $\mathrm{i}$, time $\mathrm{t}$

a $\quad=$ Intercept term

UEit = Unexpected earnings for forecast $\mathrm{i}$, time $\mathrm{t}$ for U.S. firms

UEEit = Unexpected earnings for forecast i, for European firms

MBit = Market to book value of equity as proxy for growth and persistence

Bit $\quad=$ Market model slope coefficient as proxy for systematic risk

MVit = Market value of equity as proxy for firm size

eit $\quad=$ error term for forecast $\mathrm{i}$, time $\mathrm{t}$

This equation indicates the regression model that is used to assess the information content of the earnings forecasts for both U.S. and European firms (b1 and b2 variables). In addition, an assessment is also made for total for other variables that have shown significance in prior studies such as growth, risk and size (b3, b4 and ,b5 variables).

The coefficient $b_{1}$ is the earnings response coefficient (ERC) for all U.S. firms. The coefficient $b_{2}$ represents the ERC for all European firms. The coefficients $b_{3}, b_{4}$, and $b_{5}$ are contributions to the ERC for all firms in the sample. To investigate the effects of the information content of management forecasts on ERC, there must be some control for variables shown by prior studies to be determinants of ERC. For this reason, the variables represented by coefficients $b_{3}, b_{4}$ and $b_{5}$ are included in the study.

Unexpected earnings $\left(\mathrm{UE}_{\mathrm{i}}\right)$ is measured as the difference between the management earnings forecast $\left(\mathrm{MF}_{\mathrm{i}}\right)$ and the security market participants' expectations for earnings proxied by consensus analyst following as per Investment Brokers Estimate Service (IBES) $\left(\mathrm{EX}_{\mathrm{i}}\right)$. The unexpected earnings are scaled by the firm's stock price $\left(\mathrm{P}_{\mathrm{i}}\right) 180$ days prior to the forecast. This is illustrated in Equation 3:

$$
U E_{i}=\frac{\left(M F_{i}-E X_{i}\right)}{P_{i}}
$$

This equation is used to assess unexpected earnings. Unexpected earnings is measured as the difference between the management forecast of earnings and the expected earnings level as determined by consensus analyst following per Investment Brokers Estimate Service. This value is then deflated by the firm's stock price 180 days prior to the forecast.

For each disclosure sample, an abnormal return (ARit) is generated for event days $-1,0$, and +1 , where day 0 is defined as the date of the forecast disclosure identified by the DJNRS for U.S. firms and Worldscope for European firms. The market model is utilized along with the CRSP equally-weighted 
market index and regression parameters are estimated between days -290 and -91. Abnormal returns are then summed to calculate a cumulative abnormal return (CARit). Hypotheses 5 and 6 are tested by examining the coefficients associated with unexpected earnings during economic expansion $\left(\mathrm{b}_{2}\right)$ and economic contraction $\left(b_{3}\right)$.

\section{HYPOTHESIS 3 RESULTS}

Hypothesis 3 tests information content of management forecasts for both U.S. and European firms. Table 5 reports the results of this test. As indicated in Table 5, for U.S. firms, the coefficient representing the overall ERC for all U.S. firm forecasts $\left(b_{1}\right)$ has a value of 0.22 with a p-value of .01. This is consistent with prior management forecast literature regarding information content. The coefficient representing the ERC for all European firm forecasts $\left(b_{2}\right)$ has a value of -0.15 with a p-value .01 . All other control variables are not significant at conventional levels. These findings indicate that U.S. firm forecasts contain information content which users would interpret as being meaningful. With respect to European firm forecasts, the information content is interpreted as being noisy in nature and less meaningful to users. Hypothesis 3, therefore, which states that there is no differences between the two groups must be rejected.

\section{TABLE 5}

\section{TEST OF INFORMATION CONTENT OF MANAGEMENT FORECASTS}

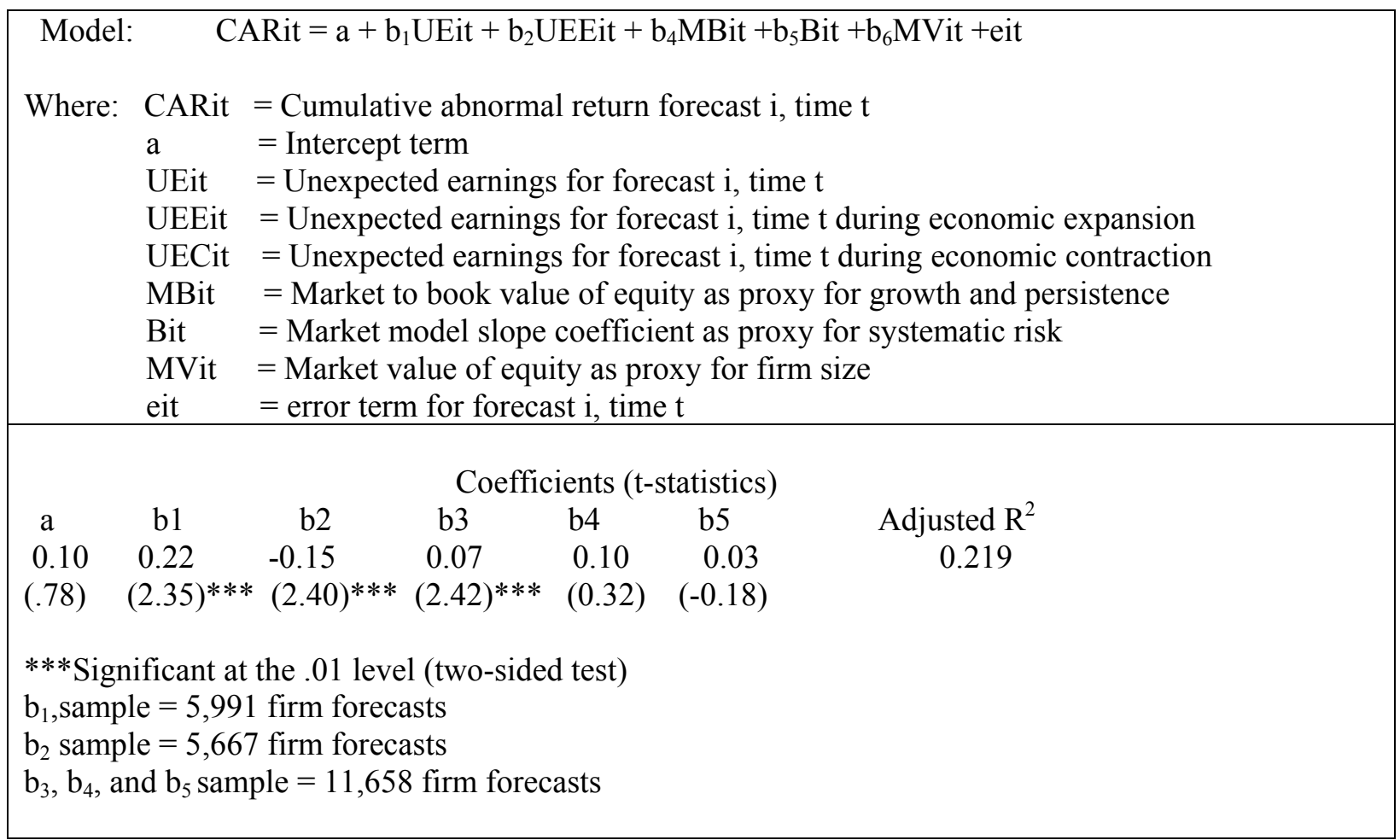

\section{CONCLUDING COMMENTS}

This study provides empirical evidence regarding the credibility of management forecasts of earnings for both U.S. firms and a sample of firms from nine European countries. This research takes into consideration 18 years of data which spans both economic expansion and contraction periods. In addition, past studies focus almost entirely on U.S. firm forecasts. This study is an attempt to draw a distinction between U.S. firm forecasts and European firm forecasts over a broad period of time. 
Bias results indicate that U.S. managers exert greater downwards earnings management on the forecast (relative to actual earnings), while European managers tend to exert more upwards earnings management on the forecast (relative to actual earnings). This is consistent with prior and current management forecast literature. Information content results indicate the presence of information content in management forecasts for both study samples. For U.S. firms the information content is significantly positive indicating a positive information-enhancing signal to users. However, for European firms the information content is significantly negative, meaning that users interpret the forecast as being more noisy and potentially less informative

As U.S. GAAP aligns more closely with IFRS standards over time, the analysis of U.S. and European firms becomes more critical from the perspective of global management and investment. The findings of this study have significant implications for managers and investors with current or potential international holdings.

\section{REFERENCES}

Ajinkya, B., \& Gift, M. (1984). Corporate managers earnings forecasts and symmetrical adjustments of market expectations. Journal of Accounting Research, (Autumn), 425-444.

Alford, A. (1993). Informativeness of accounting information disclosure in different countries. Journal of Accounting Research, 31, 183-223.

Anilowski, C., Feng, M., \& Skinner, D. (2010). Does earnings guidance affect market returns? The Journal of Accounting and Economics, 44, 36-63.

Arnold, J., \& Moizer, P. (1984). A survey of the methods used by U.K. investment analysts. Accounting and Business Research, 14, 195-207.

Baginski, S., Hassell, J., \& Waymire, G. (1994). Some evidence on the news content of preliminary earnings estimates. The Accounting Review, (January), 265-271.

Baldwin, B. (1984). Segment earnings disclosures. Accounting Review (July), 376-389.

Basu, S. (2006). International variation in accounting measurement rules. Journal of Accounting and Economics, (Spring), 113-124.

Brown, L. (1996). Forecasting errors and their implication for security analysis. Financial Analysts Journal, 52(1), 40-47.

Capstaff, J. (1995). The accuracy and rationality of earnings forecasts in the U.K. Journal of Business, Finance and Accounting, 22(1) 69-87.

Collins, D. and L. DeAngelo (1990). Accounting information and corporate governance. Journal of Accounting and Economics, 13, 213-247.

Corporate Finance Insider (2017, January).

DeAngelo, L. (1988). Managerial competition, information costs, and corporate governance. Journal of Accounting and Economics, (January), 3-36.

DeAngelo, L. (1990). Equity valuations and corporate control. The Accounting Review, (January), 93-112.

Diamond, D. (1985). Optimal release of information by firms. The Journal of Finance (September), 10711093.

Diamond, D., \& Verrecchia, R. (1987). Constraints on short-selling and asset price adjustments to private information. Journal of Financial Economics, 18, 277-311.

Dreman, D., \& Bery, M. (1995). Analyst forecasting errors and their implications. Financial Analysts Journal, 51(3)3, 30-41.

Fogarty, F., \& Rogers, J. (2014). IFRS adoption in the U.S.? Accounting Horizons Journal, 28(4), 28-45.

Fitch Ratings Report. (2014, July).

Frankel, R., McNichols, M., \& Wilson, P. (1995). Discretionary disclosures and external financing. The Accounting Review, (January), 135-150.

Haider, J. (2012). Sovereign credit risk in the euro zone. World Economics, 13, 123-136.

Hopwood, W. (1982). The potential gains in predictive ability through segmented annual earnings. Journal of Accounting Research, 20(2), 724-732. 
Lang, M., \& Lundholm, R. (1996). Corporate disclosure policy and analysis behavior. The Accounting Review, 71(4), 467-492.

Lees, F. (1991). Public disclosure of corporate earnings forecasts. New York: The New York Conference Board.

Lehman, E. (1975). Nonparametrics: statistical methods based on ranks. San Francisco: Holden-Day Press, 171-175.

Miller, R. (2009). Should managers provide forecasts of earnings? Journal of Accounting Research, 40(1), 173-204.

Patell, J. (1976). Corporate forecasts of earnings per share and stock price behavior. Journal of Accounting Research, (Autumn), 246-276.

Pike, R. (1993). The appraisal of shares in the U.K. and Germany. Accounting and Business Research (Autumn), 480-499.

Rees, W. (1998). A valuation based test of accounting differences in Europe. University of Glasgow Press, May, 1-28.

Saudagaran, S., \& Biddle, G. (2002). Financial disclosures and foreign stock exchanges. Journal of International Financial Management, 4(2), 106-148.

Stotz, M. (2016). An empirical study of financial analysts earnings forecast accuracy. Working Paper, University of Sciences and Technology of the China School of Management, 1-122.

Stunda, R. (1996). The credibility of management forecasts during mergers and acquisitions. American Academy of Accounting and Finance, (December), 352-358.

Stunda, R. (2003). The effects of chapter 11 bankruptcy on earnings forecasts. Accounting and Financial Studies, 7, 75-84.

Vergossen, R. (1993). The use of annual reports in the Netherlands. European Accounting Review (September), 219-244. 